\title{
Potentialities of the Egúngún festival as a tool for tourism development in Ogbomoso, Nigeria
}

\author{
D. O. Makinde \\ Department of Fine and Applied Arts, Obafemi Awolowo University, \\ Ile-Ife, Nigeria
}

\begin{abstract}
The Ogbómòsó people like their kinsmen in other Yoruba towns of Southwestern Nigeria, celebrate the Egúngún festival in honour of their dead. This festival is organized annually to appease the ancestors and to seek protection, blessing, favour and prosperity in all their endeavours. It is in their belief that the festival provides an opportunity for a reunion between the dead ancestors and the living members of their family. Like many other festivals in Yoruba land, the festival brings together people who live at home and abroad for various reasons. During this period an unprecedented rise in population is observed. The Yoruba, with specific reference to the Ogbómòsó people are religious and this can be seen in the number of churches, mosques, shrines, temples and other places of worship located within their towns. In the light of the above, the number of visitors to this annual Egúngún festival in the last ten years has also been on the increase. This paper comments on some results of a research conducted by the author between June, 2001 and June, 2010 in Ogbómòsó, South-western Nigeria Yoruba town. It also examines the status of Egúngún in the past and present time. The study looks at the impact of this festival on the economy of the people and that of the community. Furthermore, the paper queries the relationship of other tourism sectors to the Egúngún festival. The study also considers through interviews the reasons for the ever increasing number of visitors to this festival. Therefore, the paper concludes that the Egúngún festival has potential for tourism development if it is properly packaged.
\end{abstract}

Keywords: ancestor, escort, tourism, festival, cult, tourism development, costume, ritual, aso ebi, charms. 


\section{Introduction}

Though tourism is one of the world's fastest growing industries, its development in Nigeria is very recent. However, a recent call for tourism development by the federal government in the last decade is a shift from its traditional conservative position that relied mostly on agriculture and crude oil economy [3]. As part of its effort to create a new image for the country, the federal government recently got approval for the listing of some cultural sites in three states which include; Osun grove in Osogbo, Idanre hill and Ikogosi (warm and cold spring) in Ondo State as world heritage sites. The above confirms government interest and involvement in the tourism industry. It further shows government readiness to improve and sustain its internally generated revenue (IGR). To further demonstrate its commitment and sincerity in the tourism industry, a rebranding exercise for the national tourism initiative was launched where tourism was declared a perfect sector with attractive incentives attached to the industry [3].

In Nigeria and most other African countries, tourism is an emerging sector of our economy and as such we need to understand its basic concept. Tourism has been defined as travel for recreational, leisure, religious, educational or business purposes [4]. The justification for the above definition is found in the facts that, a great number of people come from home and abroad to participate in the programme annually. It is a process that involves activities and strategies to promote market and coordinate numerous tourism activities in the country which aims at achieving specific objectives [3]. In line with the above, [4] explains that tourism development is a strategy to improve a country's internal and external earnings in order to meet up with the challenges of the times and in line with the tourism policy of the country. In 1992, the Federal government through decree 81 established the Nigerian Tourism Development Corporation [3]. This of course, is a step towards establishing a virile and sustainable tourism industry in the country. Some of the services rendered by this corporation are largely in the area of regulation and promotion of tourism activities in the country which include; coordinating and promoting major tourism/cultural events, as well as locating other available traditional festivals that will attract local and international tourists to the country. Since most of the activities associated with tourism involve travel, lodging, feeding and other tourism activities, using the Egúngún festival as a medium towards tourism development seems very appropriate.

Several scholars (foreign and local) associate Egúngún to the Yoruba traditional religion while some see it as spirits of the ancestors who come to bless their living family members through rituals and performance annually. These include [5] who refers to the Egúngún masquerade as the spirits of the deceased 'ará ọrun kinkin' the dwellers of heaven. [6], in support of the formal mentions the religious relevance of Egúngún to the life of the people; she also explains that Egúngún is more than just the dead relatives because they play an active role in the daily life of the living [5] and [7] agree that there are numerous ways by which ancestors communicate with the living. [8] mentions that; one of the most unique ways to worship ancestors is their manifestation on earth in the 
form of masked spirits known as Egúngún. From the foregoing, one can conclude that, the celebration of the Egúngún festival is both religious and social.

Therefore the study attempts to provide answers to the following questions. What is the concept of Egúngún among the Yoruba? Are there social, economic or political advantages in this festival? What are the potentialities and possibilities of Egúngún festivals for tourism advantage? What are the indexes of tourism advantage and how has the Egúngún festival been able to achieve this. To achieve the above, the study x-rays the role of some selected Egúngún genres, spectators and visitors through random sampling and interview technique. A number of economic variables were also questioned, such as the number of visitors to hotel, restaurant and other recreational centres.

\section{Study area}

The celebration of Egúngún spreads across Yoruba land which includes Ogbómòsó in Nigeria. The festival is an annual event which holds between seven, ten and twenty-one days depending on the town or circumstances of the period. In Ogbómòsó, Egúngún celebrations last for seven days. Due to ever increasing numbers of visitors that attend and participate in this festival, Ogbómòsó has been selected for this study. The town has two local governments (Ogbómòsó North and South) which play host to ten commercial banks, sixteen standard hotels, 24 restaurants, several beer drinking joints, one state hospital and 25 maternity centers. There are 4 main garages and 18 local ones, and several motor cars/bike for transport services.

\section{Methodology}

Ten out of fifty, representing twenty percent Egúngún genres that regularly perform in the annual dance festival in Ogbómòsó were selected. The choice to study just twenty percent of the total number of Egúngún is for effective and thorough management of the information and data gathered. Ten visitors were randomly selected to talk on each Egúngún and the festival while each of the ten Egúngún was also interviewed before and after the annual performances. Information obtained from spectacles includes spirituality, modernization, continuity, acrobatic or theatrical display and acceptability of each Egúngún based on their own observation and assessment.

\section{Research finding}

Studies confirm that most ancient and contemporary Egúngún use less or no rituals and sacrifices or charms which were used against rival Egúngún in time past. The use of magical substances during Egúngún performances has also reduced to the barest minimum. According to most respondents interviewed, use of magical powers is no longer fashionable due to the wide acceptability of the 
two foreign religions (Christianity and Islam). Confirming this, only four out of eleven respondents confirmed the use of magic while seven were opposed to it. Also, thirteen respondents confirmed the use of rituals while twenty out of thirtythree confirmed non use of rituals during their annual dance festival. From the information given above, it can therefore be concluded that the Egúngún festival today has more social content than religious. The spectators and on-lookers' response to the use of modern and fashionable costumes by Egúngún adds to the interest of the spectators; this signals a positive development. While twenty-five of the respondents confirmed a change in the masquerade costume, twenty-seven out of thirty-three of them confirmed the use of foreign textile materials.

In addition, twenty-eight out of thirty-three respondents attested to wide acceptability of Egúngún in recent times. The theatrical performances and acrobatic display are some of the activities that many people enjoy most in this annual Egúngún festival. Quite a good number of people (95\%) were positively disposed to Egúngún performance. They also confirmed their support for cultural development and willingness to support culture continuity. The use of aso-ebi by supporters of these Egúngún add colour to the whole scene and it also serves as indicator of cultural and social identity. The use of uniform dresses by every group of masquerades assists the visitors or the on-lookers to establish each masquerade in the picture plain of the whole scenario.

\section{Issues in the Egungun festival}

There are many books, journal articles, magazines and texts in electronic and printed medium on Yoruba masking tradition. These include [9] and [10] who discuss Egúngún tradition in a book titled "Gelede spectacle", a masquerade type among the Egbado, a Yoruba subgroup in Southwestern Nigeria. [11] discusses Yoruba Egúngún costume, performances and rituals. In the same vein, [12] writes on classification of Yoruba Egúngún genre while [13-15] and [6] comment on traditional Yoruba Egúngún festivals while [5] writes on colour symbolism in Yoruba Egúngún costume, [1] in an unpublished long essay writes on the reconstruction of Ajomogbodo (Egúngún agba) costume genre of Yoruba Egúngún. In spite of the Egúngún festival's long standing history and continuity of the programme, there is a dearth of information on the use of Egúngún festivals for tourism development in Ogbómòsó.

Festivals are rituals which recur at regular intervals and which have as their purposes, the expression of beliefs held by a particular community. [16] affirms that, the Yoruba people believe that new yam must not be eaten or taken to the market until the yam festival (odún isu) has been celebrated to appease the gods to guarantee future harvest. There is also the conscious expectation by the Yoruba that certain very specific positive ends will come about as a result of the performance of the festival. The performance is motivated by the desire to gain some form of satisfaction and is expected to be effected. The above confirms the essence of the Egúngún festival among the Yoruba people of Southwestern Nigeria which is done to honour their dead ancestors and to provide opportunity for a reunion of the living and the dead. [10] remarks that festivals take place at 
special times set aside by a community in order to commemorate some events of historical, cultural or religious significance, and by the performance of certain rituals, such events are re-enacted, giving both individuals and their communities a sense of meaning and cohesiveness [5]. The above clearly supports the importance, purpose and significance of festivals in Yoruba land.

\section{Yoruba concept of festivals}

[17] identifies two types of festivals in Yoruba land: ojo ose (holy day) and odun (annual festival).Ojo ose (holy sacred day) are the days designated to worship some minor divinities; these are often referred to as minor festivals. There are minor festival days of some divinities called Ojó òsè (holy or sacred day). They are often at five-day, seven days: seventeen-days or twenty-one day interval depending on the divinity. The ojó òsè (sacred days) of Òrì̀̀-nlá (the archdivinity) for example is a five-day interval whereas the divinity called Bùrúkù (anti-wickedness divinity) in Abeokuta has its sacred days on the seventeenth day, this is called òsè bùrúkù (The sacred day of buruku).

The other type of festival is called odún (annual festival). Ojo ose is used to worship some divinities like orisa- nla (arch-divinity), while odun is a major festival which is celebrated annually like Egúngún (masquerade), oro (cult of the departed spirit), and odun isu (yam festival). We are concerned with the annual festival in this chapter. Odún is used to express both the seasonal cycle and annual festivals. In this sense, odún is both "year" and "festival". Again, major festivals come up every season or year and it varies from town to town. This explains why Yoruba people pray at festival that $\grave{A}$-sèyí-sà módún (just as we celebrate this festival, we will celebrate another year) or $\dot{A}$-se-se-tún-se, bi a bá sèyí tán, a ó tún se èmí sí (An endless celebration through repeated celebrations, when we celebrate this to the end, we will again celebrate others in addition). This odún (festival) is described as à se-se-tún se (that which is done repeatedly) providing opportunity for otùn (newness, renewal).

Among the Yoruba, each divinity has an annual festival associated with him or her. Unlike ojó òsè (sacred day) which involves a group of worshippers, the odún (festival) is usually the concern of the whole community and the head of the community. Hence, the Yoruba say: Gbogbo odún ni odún oba (Every festival is the concern of the king). At this juncture, we shall note that not all traditional festivals are universally celebrated by the Yoruba since not all divinities are universally worshipped by them. Consequently, the other festivals that are commonly celebrated throughout Yoruba land are Oro (in honour of the departed spirits) and Egúngún (an ancestral cult). Indeed, the Egúngún is almost omnipresent in Yoruba land. In all cases, the universal belief in the existence and power of the prominent divinities and the ancestral spirits makes people everywhere worship them for protection, prevention, purification or for anticipated rewards or blessings.

It is common knowledge that among the Yoruba people of South-western Nigeria, they always find reasons (protection, healing, blessing, joy, etc.) to celebrate a festival. Everywhere in Yoruba land, each community, town or 
village has something to celebrate in the form of a festival. However, we cannot have a thorough grasp of this phenomenon without adequate reference to Yoruba religions. It is in this regard that I refer to [18] observed that: Feasts and Festivals are an important aspect of any religion. They serve a two fold purpose of keeping religion alive and affirming some religious or theological truth connected with them... almost invariably all festivals are celebrations of some important religious principles of theological truth.

In the traditional times, sacrifices (including animals and human) and other forms of rituals were carried out before the Egúngún makes public appearance. This is to appease witches and witchcraft in the society and to guarantee a successful outing. Incantations and use of magical substances were standards of a powerful Egúngún in time past or sometimes the ability to perform magic and humiliate other Egúngún masquerade. Egúngún and members of his cult make sacrifices and rituals to appease the unseen spirits for acceptance. It is also a common practice for Egúngún to secure himself spiritually with many magical substances (oogun) and weapons which he could use freely at the opponent during public performances. The above serves as a deterrent to members of the public who are not Egúngún cult members and creates fear in their minds. Since the introduction of Islam and Christianity to Yoruba land, the culture of human sacrifice has stopped.

\section{The Egúngún festival in Ogbómòsó}

Ogbómòsó is a South-western Yoruba town, located in the savannah grassland area of Nigeria. The place is generally between longitudes 4o 17' E and between Latitudes $8^{\circ} 8^{\prime} \mathrm{N}$ and $8^{\circ} 14^{\prime}, \mathrm{N}$ [1]. It is the second largest city in Yoruba land. Before the advent of colonization and globalization, agriculture has been its mainstay. The economy of the town relied heavily on the production of staple foods like yam, cassava, maize and vegetable. The production of indigenous arts and crafts like cloth weaving, dyeing, pottery, carving and smiting are also significant in her economy.

During the festivals, it is upon the priests and family leaders to invoke and bring out the ancestors so that they can participate in the celebrations together with the people. There are elaborate costumes which the Egúngún dancers adorn as they participate in dancing and drumming. In the course of dancing and drumming, the masqueraders become possessed with the ancestors' spirits such that other people are able to experience the presence of the ancestors through this possessed state. As the festivals progress, the community is cleansed and made spiritually clean from any form of immoral and unethical activities which they might have engaged in since the previous festival. The presence of the spirits is aimed at encouraging the Egúngún community to live their lives in a manner that pleases the spirits especially by adopting their mannerisms. After the cleansing, any information which the ancestors may be willing to convey such as warnings and blessing is relayed to the participants. Examples of Egúngún include Ajomogbodo, Kongba, Oya, Olukotun, Danafojura, Kindin, Aribidara, Ayilere Oroko, Babalugbon and many others. 
Like many other Yoruba sub group, Ogbómòsó people have a masquerade tradition which they refer to as the 'Egúngún festival'. This festival is celebrated in the month of June before the new yam is harvested annually. [1] asserts that the festival brings together the living members of the family and their dead ancestors in a ceremony (the Egúngún festival). Previous studies on traditional festivals confirmed their uses for tourism development in Nigeria. These include the Argungun fishing festival in Kebbi State, the Osun festival in Osogbo and Durbar in Kano and Bauchi to mention but a few. This however excludes the Egúngún festival which has been adjudged the most popular traditional festival of the Yoruba people of Nigeria [3]. It explains further that the government has not really done much to discover yet more of such traditional festivals like Yoruba Egúngún for tourism advantage. A participant survey of traditional festivals (Egúngún) by the author in Ogbómòsó reveals that, a calendar (odún eégún) is worked out to fix the date and period of the festival. Usually, the celebration covers a seven-day period. The festival is held between the second and third week in June every year]. Secondly, once the date is fixed, elaborate preparations are made towards the festival. [19] remarks that in time past, the town crier beat his gong to alert and sensitize the public to the proposed festival. In this day of technological advancement, things have since changed. The festival is usually characterized by merry-making, entertainment, singing, drumming, dancing, procession and feasting members of the Egúngún cult, neighbours, family and friends. The coming together of the people is re-enacted, and many people for the first time in the year meet on this occasion. Men and women are brought together in one crowd, and there is usually a sort of social reunion. Again rituals and rites come into prominence during the festival. People thank divinities or ancestors for the blessings of the previous year and ask for protection against enemies, evil, and epidemic [10]. This is usually done at the Egúngún shrine (ile sanyin) Even when people exchange greetings on festival occasions, they also pray for one another and wish one another well," as we celebrate this year, so it shall be next year" ( A seyi se amodun o).

The Egúngún festival in Ogbómòsó is characterized by renewal of relationship and family solidarity. It also helps to resolve agelong disputes quarrels, misunderstandings, and family and community problems during this. According to [14], Egúngún is robed from head to foot in a variety of dresses (costume), and he sees only through a net covering his face. It is absolutely essential that the whole body is concealed. The dress of an Egúngún gives people the impression that he is from the spirit world. In order to preserve this illusion, the Egúngún speaks in a voice that disguises the guttural character.

As part of the taboos associated with the myth of Yoruba Egúngún, women are not allowed to know the secret (rituals and rites) of the cult (Egúngún) except a woman of strong personality called Iya Agan (the foster mother of agan). [9] confirms that iya agan is let into the secret of the cult, and she participates fully in the activities of Egúngún. Again, the Egúngún appears in the day-time either singly or in small companies usually with atókìn (escort) who accompanies the Egúngún. 
Though the time of the Egúngún festival in Yorùbá land varies from town to town, and in most cases, they last for seven days in Ogbómòsó. The festivals are usually preceded by igbágan (an all night vigil) in the Igbó İgbàlè (the sacred grove). This is called ojọ́ ikúnlè Egúngún (the kneeling day of Egúngún). The day is devoted to kneeling down and offering prayers to the ancestors in the grove. On the morning of the festival, the people go to the central Egúngún shrine and from there, the Egúngún dance to the house of the king to receive his homage and blessings. From there, they dance round the town. It is said that a person who does not take part in this opening ceremony cannot parade his Egúngún that year. [18] identifies two main types of Egúngún in Ogbómòsọ́; the young Egúngún (kunduke) and the elder Egúngún (eegun agba).

The young Egúngún carries a whip, and drives people away with it whenever he decides to act tough. The young Egúngún also dances to please and entertain people, and he receives gifts of money. Throughout the period of the festival, the young Egúngún is found going about dancing, and the better his skills in dancing, the more gifts he will receive. Thus, the Yoruba say: Bí Egúngún eni bá mọ ọ́n jó, orí a yá atọkùn rẹ̀ (If the Egúngún dances well, the escort delights in his performance). Orí ki ni Egúngún $n$ wò tí kò fi òwúrọ jó? (What is the Egúngún waiting for that he cannot begin to dance in the morning?). Thus, dancing is one of the important activities of the Egúngún during the festivals.

However, the elder masquerade (Egúngún agba) may wear a wooden mask or carry a huge image whose frightening appearance depicts or symbolises their power. Indeed, the elder Egúngún is feared for his magical powers [10].He does not go out frequently like the young Egúngún and when he does, he usually has a large following. The festival is an occasion for the elder Egúngún to display charms and magical tricks in the form of contest. Some of the people who follow powerful Egúngún carry offensive weapons and use bad magic freely. The followers of powerful Egúngún are usually armed with protective magic (isora, gbekude, aferi, ifunpa...). Each Egúngún dares the other to cross his path or meet him during the procession. People run away at the approach of such powerful Egúngún [20].

Frequently, the elder Egúngún is accompanied by drummers. Some older Egúngún usually become excited at the sound of the talking drum, and they are only controlled from being too wild by their escorts. For example, there was a powerful Egúngún in Ogbómòsọ́ called Babalugbon; The presence of this Egúngún is heralded by the shout of "ko lo jugun gbe ojugun; Je kolomo gbe omo re pon "babalugbon n'bo" let the owner of the knee bend it and let the owner of the child put the child on the back in readiness for running; babalugbon is approaching). At the sound of the drum, the Egúngún ran furiously anywhere and everywhere dangling his axe which he carried. The drummers ran after him while the crowd following them destroyed anything they laid their hands on. The tension only subsided when the drummers beat slowly and the escort grabbed the Egúngún.

This study confirms that many of the aforementioned character of these Egúngún genres have changed and mostly taken over by the influence of the two foreign religions (Christianity and Islam), and other agents of civilisation. For 
example, Egúngún costume used to be manufactured from Yoruba woven fabrics (kijipa) but now dominated by foreign textile materials like; Damask, Ankara and Guinea and other accessories. Egúngún costumes are now very rich with their irresistible panel of bright colours; red, yellow, green, orange and black.

This research will not be complete if we fail to mention modern tendencies in Egúngún festival as it is celebrated in Ogbómòsó. The inclusion of academic programmes by Aribidara masquerade family, like: lecture series on Yoruba culture, competition in traditional Ayo games and all-night dance party that comes as prelude to Egúngún performance proper. More importantly, the reduction or absence of the use of rituals, magic or other forms of human sacrifices have reposed confidence in the minds of the society and visitors in the last decade. In support of the above confirms a large and ever increasing turnout of people from 2001 Egúngún festival to date. This, according to [19], shows an evidence of assimilation and acceptability of Egúngún festival in Ogbómòsó.

Another programme that supports the tourism potentials of Egúngún festival in Ogbómòsó is the inclusion of elaborate feasting, musical jamboree, dance competition and general entertainment on a night prior to the festival "aìsùn Egúngún" among the Yoruba. A local musician is often invited to entertain the people at the family compound (agbo-ile). Prior to this time the relations or members of each Egúngún family, friends and other well wishers often donate cows, money, drinks and other materials as a mark of solidarity and to ensure the success of the festival. As part of the new development (this forms the colourful part of the festival), the study confirms the use of așo-ebi (uniform dress) by every member of Egúngún cult, their family and well wishers. This is also a recent development that adds colour to the festival. The așo-ẹbi is used to denote family and friend's solidarity and social identity. The parade and performance of each Egúngún group is another interesting aspect of the festival which allows the on- lookers to confirm the popularity, superiority and acceptability of each of the Egúngún genre in the society. This continues till the crowd population decreases.

\section{Conclusion}

It is a certainty that the Egúngún festival in Ogbómòsó goes through a period of transition whose main characteristic is the emergence and the continuous increase of a new category of Egúngún tourists. It is pertinent therefore to mention here that the innovations incorporated into the festivals programme like; lectures, symposium, game-competition (ayo) and social parties are responsible for this. The study established a relationship of the Egúngún festival to tourism development because of the ever increasing number of spectators during the festival annually. Equally, this study confirms the impact of technology, acculturation and globalisation on the physical appearance of Yoruba Egúngún. Egúngún costume used to be manufactured from locally woven Yoruba fabrics (aso oke). Aso oke is limited in colour, texture, and pattern. Besides, it is no more in vogue even within the people for some personal reasons Today, most Egúngún costume are produced from imported textile material and accessories which 
make them look corporate and friendly. Besides, the Egúngún festival is characterised by renewal of relationships and solidarity. Disputes, quarrels, misunderstandings, family and community problems are settled during festivals which bring people together, both those who live at home and those who live abroad. Bearing this in mind, it means that as long as the Yoruba people continue to rely on their traditional beliefs the Egúngún festival shall continue to thrive and tourists will continue to multiply.

The unprecedented crowd generation and the presence of other tourism related sectors like hotels, restaurants, recreational centres, hospitals, banks coordinated and functional public transport systems and many others during the period make the Egúngún festival a viable instrument for tourism development in Ogbómòsó. During this period tourists' demand for food transport, accommodations and other tourism related services is always on the increase which consequently affects the economy of the town. Let us conclude here with the words of [21] who comments thus:

"Through festivals the life of the community is renewed. People are entertained, and their tensions find an outlet. Festivals also bring together the people as a group, thus strengthening their unity and cohesion. Religious and social values are repeated and renewed through communal festivals....People seize each occasion to solicit for blessings from God or the departed, and there is a general feeling that the visible and invisible worlds co-exist for the benefit of man who is at their centre...Rituals and festivals are religious ways of implementing the values and beliefs of the society. Without them, African life would be dull... Human life needs some relevant rituals and festivals to give it both solemnity and laughter.

Finally, all tiers of government should support and provide adequate and attractive incentives by initiating performance competitions like it is done at the Argungu festival in Kebbi, durbar in Kano and Bauchi states and many others in Nigeria. More educative cultural activities should be incorporated as spices to these programmes to compliment the local ones. It is obvious that Nigeria is tourism-endowed and the fact cannot be disputed [22]. The country with her numerous tourist attractions has shown little concern to develop these tourism potentials for local communities and their economies. This study shows that if patronage of these festivals and attractions are not delivered sensibly, there may be serious implications for both the environment and the community. To ensure that the tourism industry thrives and flourishes, we must balance the needs of visitors, the tourism industry, the local communities and the country at large. Therefore, Egúngún, like many other traditional festivals world over, could be developed to be a leading cultural tourism industry in Ogbómòsó and other Yoruba towns. This is achievable if and only when the host community, the private organisations and government authorities (federal, state and local) are willing and ready to tap the potentials. 


\section{References}

[1] Makinde, D.O. (2005), Reconstruction of Egungun Ajomogbodo costume; unpublished M.F.A. thesis, O.A.U. Ile-, Ife, Nigeria.

[2] Opoku, K.A. Religious theme in West African Festivals. Journal of international Religious foundation .Vol. 4, No 1, 1990 pp.71.

[3] Nigeria Tourism Development Corporation (N.T.D.C) www.nigeriafirst.org, 2011

[4] Wikipedia (.2006) www.en.wikipedia.org/wiki/special.

[5] Aremu, P.S.O. 'Spirituality and Physical identity of Yoruba Egungun costumes.London, 1998.

[6] Laura, S. The masked ancestors of the Yoruba www.mythicalarts.com /writing/Egúngún.2011.

[7] Dopamu, P.A., West African Traditional Religion, Ibadan.1979 pp.149.

[8] Idowu, E.B Olodumare; God in Yoruba Belief. London; Longmans. 1962.

[9] Pemberton, J., Egungun masquerades of the Remo Yoruba. African Arts Vol. 11, pp 41-44. 1978

[10] Lawal, O.O. Yoruba traditional festivals, London, 2004.

[11] Okediji, M Transformation Through cloth, African arts vol.28 no 2, pp.5457, (2006).

[12] Adepegba, C.O), Intriguing Aspects of Yoruba Egungun Masquerades, The Nigerian Field.vol.55.pp, 3-12. 1990

[13] Olupona, J.K. (2008) Orìşà devotion as world religion: the globalization of Yorùbá religious culture, New York. pp.88-103

[14] Awolalu, J.O Yoruba traditional Festival, U.P, Ibadan.1979,

[15] Babayemi, S.O., Egungun among Oyo Yoruba. Onibonoje press, Nigeria. 1980

[16] Personal interview with Ojekanmi, S.E. one of the Egúngún cult elder (alagbaa), Ogbomoso. June, 17, 2010.

[17] Personal interview with Mr. Apiah Osei, a Ghana born tourist in Ogbomoso.

[18] Personal interview with. Gbadamosi, P.O., a renowned Egúngún drummer of Ayilara compound Ogbómòsó on the June 25, 2010.

[19] Personal communications with Adepoju, W, the coordinator of Egúngún aribidara in Ogbómòsó on the $15^{\text {th }}$ of June, 2010.

[20] Personal communication with Ojetunji, S.A, An Egúngún escort (atokun egun) in Ogbómòsó on the 17th of June, 2010.[21]

[21] Nirma A.P. (1976), Celebration of Indian Festivals, Day Star Press, Ibadan.

[22] Omisore, E.O. (2010), "A Study of the patronage of tourism site in Osun State" unpublished faculty seminal paper, 